\title{
Biological Probiotic Properties of Lactobacillus rhamonosus GG-4 Isolated from Infant Feces
}

\author{
Jin Hae Kang, Dae Hwan Kim, Sang Won Lee, Hong Chul Kim, Young Un Cho and Sang Wan Gal*
}

Department of Pharmaceutical Engineering JinJu National University, JinJu 660-758, Korea

Received November 5, 2010 /Accepted December 15, 2010

\begin{abstract}
To develop probiotics, a kind of Lactobacillus sp. was isolated from infant feces. The bacterium was identified as Lactobacillus rhamnosus through $16 \mathrm{~S}$ rDNA sequence analysis. The strain was a facultative anaerobe which grew better in aerobic conditions. The bacterium lowered the $\mathrm{pH}$ of the culture solution down to 2.4 during $48 \mathrm{hr}$ in the MRS medium. The strain inhibited the growth of 6 pathogens - S. aureus, L. monocytogens, S. typhimurium, E. coli O-157, V. parahaemolyticus and P. aeruginosa. When the Lactobacillus were fed to chickens, along with commercial feed, for one month, amounts of $\mathrm{H}_{2} \mathrm{~S}$ and $\mathrm{NH}_{3}$ in the feces of the chicken decreased to $50 \%$ and $70 \%$, respectively, compared to those of control group chickens. Amounts of other bad smells such as $\left(\mathrm{CH}_{3}\right) \mathrm{SH},\left(\mathrm{CH}_{3}\right)_{2} \mathrm{~S}$ and $\left(\mathrm{CH}_{3}\right)_{2} \mathrm{~S}_{2}$ were not much different in the Lactobacillus-fed chickens compared to the control group. On the other hand, egg weights of the chickens fed Lactobacillus were higher by about $5 \pm 1 \mathrm{~g}$ than those in the control group.
\end{abstract}

Key words : Probiotics, Lactobacillus rhamnosus, industrial application

\section{서 론}

지금까지 축산업에는 여러 가축의 성장을 촉진하고 설사 등의 질병을 예방, 치료하기 위해 이용되는 사료 첨가제 중에 서 일반적으로 항생제가 가장 많이 이용되고 있다. 그러나 국 내 양돈장에는 항생제의 꾸준한 사용에도 불구하고 다양한 질병들은 감소하지 않고 있으며 항생제를 장기간 사용하거나 남용하게 되면 가축에게 내성이 생기고 축산물의 항생제 잔류 문제를 초래하게 된다[6]. 해결 방안으로 항생제 대체 물질 중 가장 각광 받고 있는 것이 생균제이다. 축산분야에서 생균제 (probiotics)라 함은 미생물 자체를 가지고 만든 제재로써 가축 의 장내에 정착하여 다른 병원성 미생물의 성장을 억제하고 [3], 섭취한 사료의 소화와 흡수를 도와주며 다른 영양소의 합 성에 도움을 줌으로써 가축의 성장을 촉진하고 사료효율을 개선시켜 주는 일종의 기능성 물질이다[10]. 또한 사료 중에 첨가했을 때 안정성이 있어야 하며 가축에 대해 해가 없어야 한다[9].

생균제의 종류로는 유산균(Lactobacillus)과 진균(곰팡이, Aspergillus, 효모, Saccharomyces) 등이 일반적으로 널리 알려 져 있는데 이 중 가장 대표적인 것으로 Lactobacillus [11]를 들 수 있으며, 이 유산균은 Salmonella와 E. coli에 의한 설사를 방 지하고 가축의 생산성을 향상시킬 수 있는 것으로 이 미 많은 유산균이 상품화되어있다. 유산균은 유제품을 생산하는 낙농 산업에 널리 사용되어 온 미생물로 장내의 유해세균을 감소시

*Corresponding author Tel : +82-55-751-3393, Fax : +82-55-751-3399

E-mail : sangal@jinju.ac.kr
키고 유익세균을 증가시키는 균총 변화 능력이 있다[1]. 또한 항균물질(박테리오신)을 생성하며 소화관 병원성 세균의 흡착 저해[8], 면역글로블린 생산 자극[5], 대식세포의 인터페론 유 도[7], 저콜레스테롤 효과[2,4] 등의 기능을 하는 것으로 알려 져 있다.

본 연구에서는 유아의 분변으로부터 병원성 세균에 대한 넓은 항균활성 스펙트럼을 갖는 유산균을 분리하고, 이들이 항생제 대체능 생균제로서 이용 가능성을 조사하였으며, 축산 분뇨의 악취를 줄이는 효과를 조사하였다.

\section{재료 및 방법}

\section{유산균 분리 및 배양}

유아의 분변으로부터 유산균의 분리는 모유만을 먹은 6 개 월 된 유아의 분변을 사용하여 실시하였다. 균주의 순수분리 는 유아분변 10 단계 희석법으로 희석한 후 MRS (Peptone $10 \mathrm{~g}$, Beef extract $10 \mathrm{~g}$, Yeast extract $5.0 \mathrm{~g}$, Glucose $20 \mathrm{~g}$, Triammonium citrate $2 \mathrm{~g}$, Sodium acetate $5 \mathrm{~g}$, Magnesium sulfate $0.2 \mathrm{~g}$, Manganeses sulfate $0.05 \mathrm{~g}$, Di-potassium phosphate $2.0 \mathrm{~g}$ per Liter, MERCK, Germany) Agar에 $0.1 \mathrm{ml}$ 씩 평판 도말하여 혐기성상태의 $37^{\circ} \mathrm{C}$ 배양기에 넣고 48 시간 배 양하여 유산균을 분리하였다.

\section{병원성 세균}

본 실험에 사용된 병원성 균주는 한국 종균협회에서 구입 한 Listeria monocytogenes, Staphylococcus aureus, Pseudomonas aeruginosa, Vibrio parahaemolyticus, Salmonella typhimurium, 
Escherichia coli $\mathrm{O} 157$ 균주를 LB ( $\mathrm{NaCl} 10 \mathrm{~g}$, Tryptone $10 \mathrm{~g}$, Yeast extract $5 \mathrm{~g}$ per Liter) 및 TSA (Pancreatic digest of casein $17 \mathrm{~g}$, Pancreatic digest of soybean meal $3 \mathrm{~g}, \mathrm{NaCl}$ $5 \mathrm{~g}, \mathrm{~K}_{2} \mathrm{HPO}_{4} 2.5 \mathrm{~g}$, glucose $2.5 \mathrm{~g}$ per Liter BD, USA) 배지를 이용하여 $37^{\circ} \mathrm{C}$ 에서 배양하며, 항균활성 측정용으로 사용하 였다.

\section{항균활성 측정}

장내 질병 미생물에 대한 항균활성 측정은 paper disc 법을 이용하여 측정하였다. 유아분변에서 분리한 25 종의 유산균을 MRS broth에 48 시간 동안 혐기적으로 배양한 배양액을 centrifuge $(15,000 \mathrm{rpm}, 5 \mathrm{~min})$ 하여 상등액만을 분리하여 활성측 정시료로 사용하였다. 먼저 병원성균을 LB Broth, 또는 TSA broth에 24 시간 배양하여 멸균된 glass bead를 사용하여 LB Agar, TSA Agar에 회전하면서 전면에 병원균 배양액을 골고 루 도말하였다. 항균측정용 시료액은 paper disc $(8 \mathrm{~mm})$ 에 $100 \mu \mathrm{l}$ 를 집적하여 $37^{\circ} \mathrm{C}$ 에서 24 시간 배양 하였다. 생성된 억제환(직경 $\mathrm{mm}$ )으로 항균 활성 효과를 측정하였다. 이 중 가장 큰 항균 효과를 가진 유산균을 선발하였다.

\section{항생제 저항성 조사}

분리된 유산균을 오랫동안 특성을 유지시키며 보존하기 위 하여 항생제 저항성 조사를 실시하였다. 유아분변과 김치에서 분리한 유산균을 48 시간 배양한 현탁액을 Kanamycin, Ampicillin, Tetracyclin, Streptomycin이 첨가 된 $\mathrm{MRS}$ 한천 배지에 도포하였다. 혐기성상태의 $37^{\circ} \mathrm{C}$ 배양기에 넣고 배양하였 을 때 해당 항생제 함유 배지의 균주 생육상태를 조사하였다.

\section{항균물질의 내열성 조사}

생균제의 가공을 위해서 항균 물질의 열 안정성을 조사하였 다. 분리균을 MRS Broth (MERCK, Germany)에 48 시간 동안 혐기적 조건하에서 배양한 배양액을 원심분리(15,000 rpm, 5 $\min$ )하여 상등액을 분리하였다. 이를 $100^{\circ} \mathrm{C}$ 에서 $0,5,10,30$, $60(\mathrm{~min})$ 을 가열하여 활성측정시료로 사용하였다. 병원성균을 LB Broth, TSA Broth에 24 시간 배양하여 멸균 된 glass bead 를 사용하여 배지 위에서 회전하면서 전면에 균 배양액을 골 고루 도말하고 가열한 상등액은 paper disc $(8 \mathrm{~mm})$ 에 $100 \mu \mathrm{l}$ 를 집적하여 병원성 세균의 적정 생육온도에서 24 시간 배양 하 였다. 생성된 억제환의 크기로 항균 효과를 확인하였다.

\section{생육 중의 $\mathrm{pH}$ 조사}

유산균은 일반적으로 생육 중에 여러 가지 산을 생성 시킨 다. 따라서 생육 중에 산 생성량을 $\mathrm{pH}$ 변화로 조사하였다. 100 $\mathrm{ml}$ MRS broth에 전 배양 된 배양액을 MRS broth $100 \mathrm{ml}$ 에 각각 $10 \%$ 를 접종하여 총 48 시간 동안 혐기적 조건하에서 배양하면서 12 시간 간격으로 $\mathrm{pH}$ 를 측정하였다.

\section{6s rDNA sequence}

분리 균을 동정하기 위하여 분리 균을 MRS 배지에 streaking하여 24 시간 배양 후 (주) MACROGEN에 의뢰하여 $16 \mathrm{~s}$ $\mathrm{rDNA}$ 염기순서를 통하여 균 동정을 실시하였다.

\section{분리균의 산란계 급이를 통한 계분 악취 감소 효과}

실험 산란계는 $\mathrm{M} \& \mathrm{M} \mathrm{BIO}$ 에서 사육 중인 산란계 10 마리 이용하였으며 비급이구(대조구) 5 마리, 급이구(실험구) 5 마 리로 구분하여 실험하였다. 실험사료는 시판 중인 닭 사료에 $10 \%$ 의 탈지분유와 $1 \%$ 의 글루코스가 함유된 배지에서 배양 된 유산균 $\left(3.2 \times 10^{10}\right.$ cells $\left./ \mathrm{ml}\right)$ 을 $10 \%$ 가 되도록 시판 중인 닭 사료에 첨가하여 1 일 1 회 $(200 \mathrm{~g} /$ 마리/일) 씩 급이하고 물은 수시로 공급하였다. 기 서식하고 있는 닭의 장내 유산균이 대 처하기 위하여 1 달간은 실험사료를 급이하였고 30 일 후부터 계분을 채취하여 밀폐시료 챔버 내에서 12 시간 보관 후 악취 물질(암모니아, 황화수고, 메틸메르캅탄, 황화메틸, 이황화메 틸, 트리메틸아민 등) 농도를 보건복지부지정 진주산업대학교 공기질 검사센터에 의뢰하여 조사하였다. 그 외에 닭의 외형 적 변화, 달걀의 무게, 노른자의 색도 등을 조사하였다.

\section{결과 및 고찰}

\section{유산균 분리 및 항균활성 측정}

유아 분변으로부터 10 단계 희석법에 의해 총 25 종의 유산 균을 분리하여 U-1, 2, 3, 4, 등으로 표시하였다. 순수분리 된 유산균을 배양하여 상등액만을 취한 다음 paper disc에 100 $\mu \mathrm{l}$ 농축하는 방법으로 집적하여 동물질병균을 비롯한 6종의 병원균에 대한 항균활성을 확인하였다(Table 1). 대부분의 분 리균은 6종의 병원균에 대한 항균력을 가지고 있었고 억제환 의 크기는 $18 \pm 2 \sim 3 \mathrm{~mm}$ 정도였다. 그 중 가장 활성이 큰 4 종의 유산균을 선발하여 각각 GG-1, GG-2, GG-3, GG-4 로 명명하였다. 6 종의 병원균에 대한 항균활성을 4 종의 유산균 애 대하여 조사한 결과 특히 GG-4가 활성이 가장 강함을 알 수 있었고 동물 병원성 세균인 L. monocytogens에 특히 강한 항균 활성을 확인 할 수 있었다(Fig. 1). 따라서 다음 실험에서 는 GG-4 만을 가지고 생균제로서의 특성을 조사하였다.

\section{항생제 저항성 조사}

분리된 유산균(GG-4)을 오랫동안 특성을 유지시키며 보존 하기 위하여 항생제 kanamycine $(50 \mu \mathrm{g} / \mathrm{ml})$, streptomycine $(50 \mu \mathrm{g} / \mathrm{ml})$, ampicillin $(50 \mu \mathrm{g} / \mathrm{ml})$, tetracyclin을 표시된 양을 기준으로 배지에 첨가 하여 항생제 저항성 조사를 실시하였 다. 순수 분리한 GG-4를 항생제를 첨가한 고체배지에 streaking 하여 colony 생성 유무를 관찰한 결과 kanamycin에 대한 저항성이 가장 뚜렷하게 나타났고 streptomycin에 약한 저항 성이 관찰되었으며 ampicillin과 tetracyclin에 대한 저항성은 
Table 1. Antibacterial activities against 6 pathogens of Lactobacillus strains isolated from the infant feces

\begin{tabular}{|c|c|c|c|c|c|c|}
\hline $\begin{array}{l}\text { Isolated } \\
\text { bacteria }(\mathrm{mm})\end{array}$ & $\begin{array}{c}\text { Staphylococcus } \\
\text { aureus }\end{array}$ & $\begin{array}{c}\text { Listeria } \\
\text { monocytogenes }\end{array}$ & $\begin{array}{l}\text { Salmonella } \\
\text { typhimurium }\end{array}$ & $\begin{array}{l}\text { Escherichia } \\
\text { coli 0157:H7 }\end{array}$ & $\begin{array}{c}\text { Vibrio } \\
\text { parahaemolyticus }\end{array}$ & $\begin{array}{c}\text { Pseudomonas } \\
\text { aeruginosa }\end{array}$ \\
\hline \multirow{2}{*}{ U-1 } & 18 & 20 & 22 & 20 & 21 & 19 \\
\hline & 18 & 19 & 22 & 20 & 20 & 18 \\
\hline \multirow{2}{*}{ U-2 } & 17 & 20 & 22 & 21 & 20 & 15 \\
\hline & 16 & 20 & 23 & 20 & 20 & 14 \\
\hline \multirow{2}{*}{ U-3 } & 18 & 21 & 24 & 20 & 22 & 18 \\
\hline & 20 & 20 & 24 & 19 & 20 & 18 \\
\hline \multirow{2}{*}{ U-4 } & 20 & 26 & 24 & 22 & 22 & 20 \\
\hline & 19 & 25 & 25 & 23 & 22 & 20 \\
\hline \multirow{2}{*}{ U-5 } & 13 & 18 & 15 & 15 & 15 & 13 \\
\hline & 15 & 17 & 15 & 14 & 15 & 13 \\
\hline \multirow{2}{*}{ U-6 } & 13 & 16 & 14 & 17 & 15 & 14 \\
\hline & 14 & 15 & 13 & 17 & 16 & 14 \\
\hline \multirow{2}{*}{ U-7 } & 15 & 14 & 19 & 18 & 13 & 15 \\
\hline & 15 & 13 & 19 & 18 & 12 & 16 \\
\hline \multirow{2}{*}{ U-8 } & 15 & 18 & 20 & 18 & 14 & 18 \\
\hline & 16 & 18 & 20 & 18 & 15 & 17 \\
\hline \multirow{2}{*}{ U-9 } & 8 & 8 & 8 & 8 & 8 & 8 \\
\hline & 8 & 8 & 8 & 8 & 8 & 8 \\
\hline \multirow{2}{*}{ U-10 } & 12 & 10 & 12 & 11 & 13 & 13 \\
\hline & 12 & 10 & 11 & 11 & 13 & 12 \\
\hline \multirow{2}{*}{ U-11 } & 18 & 11 & 10 & 17 & 17 & 17 \\
\hline & 18 & 10 & 10 & 18 & 17 & 17 \\
\hline \multirow{2}{*}{ U-12 } & 16 & 15 & 15 & 17 & 20 & 17 \\
\hline & 15 & 15 & 15 & 16 & 19 & 17 \\
\hline \multirow{2}{*}{ U-13 } & 16 & 18 & 16 & 15 & 18 & 17 \\
\hline & 16 & 16 & 16 & 17 & 18 & 16 \\
\hline \multirow{2}{*}{ U-14 } & 10 & 12 & 10 & 11 & 10 & 13 \\
\hline & 11 & 12 & 12 & 11 & 10 & 12 \\
\hline \multirow{2}{*}{ U-15 } & 13 & 15 & 15 & 12 & 13 & 13 \\
\hline & 13 & 15 & 15 & 13 & 13 & 13 \\
\hline \multirow{2}{*}{ U-16 } & 18 & 19 & 18 & 20 & 21 & 20 \\
\hline & 18 & 20 & 19 & 20 & 20 & 20 \\
\hline \multirow{2}{*}{ U-17 } & 15 & 15 & 15 & 15 & 13 & 11 \\
\hline & 15 & 15 & 14 & 14 & 13 & 10 \\
\hline \multirow{2}{*}{ U-18 } & 17 & 18 & 19 & 19 & 17 & 16 \\
\hline & 16 & 18 & 18 & 18 & 18 & 15 \\
\hline \multirow{2}{*}{ U-19 } & 10 & 11 & 10 & 11 & 10 & 8 \\
\hline & 11 & 11 & 11 & 10 & 10 & 8 \\
\hline \multirow{2}{*}{ U-20 } & 8 & 10 & 9 & 10 & 8 & 12 \\
\hline & 8 & 10 & 10 & 10 & 8 & 11 \\
\hline U-21 & 20 & 18 & 16 & 19 & 17 & 16 \\
\hline$U-\angle 1$ & 20 & 18 & 15 & 18 & 17 & 15 \\
\hline UL-22 & 13 & 14 & 12 & 12 & 10 & 15 \\
\hline$U-\angle Z$ & 14 & 14 & 11 & 12 & 11 & 16 \\
\hline U-23 & 15 & 15 & 18 & 18 & 16 & 18 \\
\hline$U-23$ & 16 & 17 & 18 & 18 & 18 & 18 \\
\hline & 10 & 11 & 10 & 10 & 12 & 13 \\
\hline U-24 & 10 & 10 & 10 & 10 & 11 & 13 \\
\hline & 8 & 8 & 10 & 8 & 9 & 10 \\
\hline$U-20$ & 8 & 8 & 10 & 9 & 9 & 10 \\
\hline
\end{tabular}



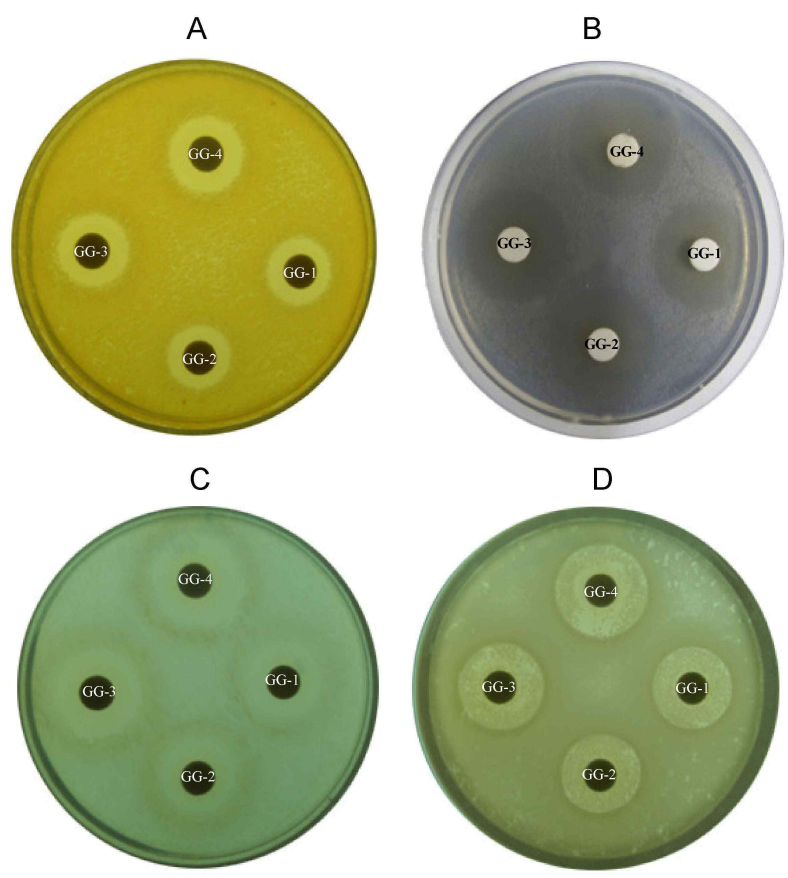

$\mathrm{E}$
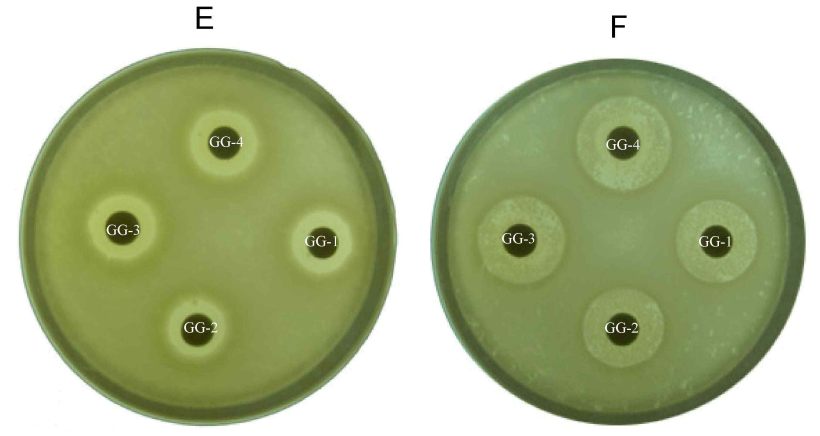

Fig. 1. Antibacterial activities against 6 pathogens of GG-1, GG-2, GG-3 and L. rhamnosus GG-4. A: $S$. aureus, B: $L$. monocytogenes, C: S. typhimurium, D: V. parahaemolyticus, E: P. aeruginosa, F: E. coli 0157

없었다(Fig. 2). 이 결과로 kanamycin을 배지에 첨가하여 배양 하거나, 장기 보존 시킬 때 이 균만을 선택적으로 보존 할 수 있음을 확인할 수 있었다.

\section{항균물질의 내열성 조사}

분리균(GG-4)의 배양액을 $0,5,10,30,60$ 분 동안 가열 후 식힌 다음 paper disc에 $100 \mu \mathrm{l}$ 씩 집적하여 동물 병원균으로 알려진 S. aureus, L. monocytogenes에 대한 항균활성에 변화가 있는지를 확인하였다. 실험 결과 1 시간 정도 가열 하였을 경 우에는 전혀 변화가 없었다(Fig. 3). 이 결과로 볼때 GG-4가 생육중에 분비하는 항균 물질은 열에 상당한 내성이 있음을 확인하였다.

특히 L. monocytogenes에 대한 항균활성은 S. aureus에 대한 항균활성보다 2 배정도 높은 것을 확인할 수 있었다.
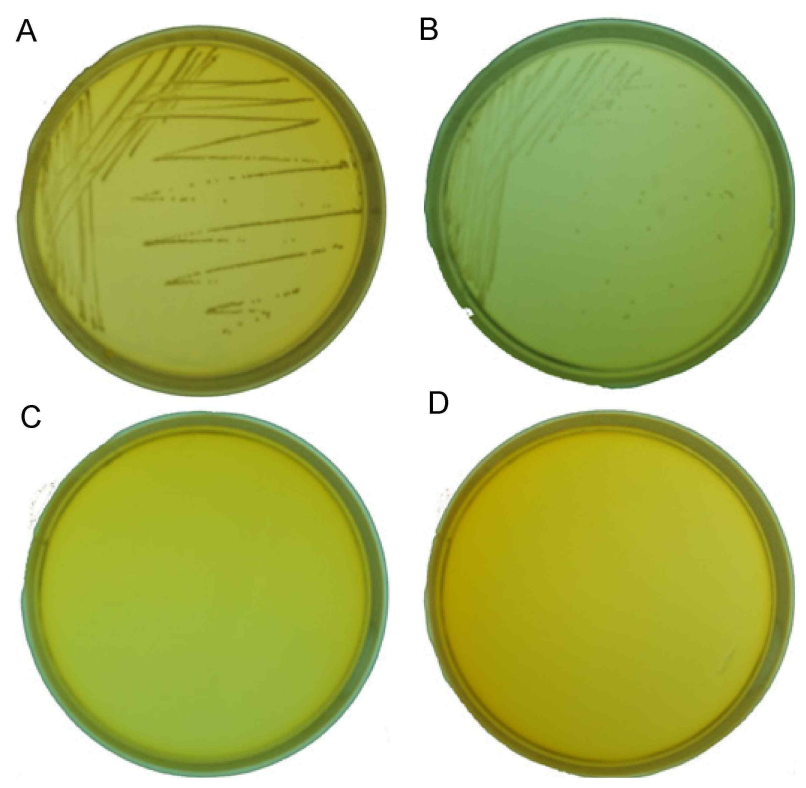

Fig. 2. Antobiotic resistance of L rhamnosus GG-4. A: Kanamycin, B: Streptomycin, C: Ampicillin, D: Tetracyclin

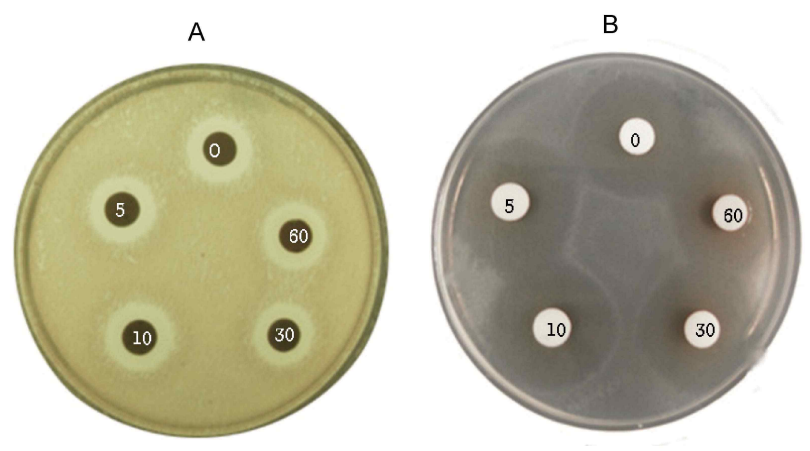

Fig. 3. Heat stability of the culture supernatent of $L$. rhamnosus GG-4. A: S. aureus, B: L. monocytogenes

\section{생육 중의 $\mathrm{pH}$ 조사}

유산균은 일반적으로 생육 중에 여러 가지 산을 생성 시킨 다. 따라서 생육 중에 배지의 $\mathrm{pH}$ 를 3 4 이하로 낮춘다[12]. 분리한 GG-4 균이 유산균임을 확인하기위하여 배양 중 배양 여액의 $\mathrm{pH}$ 변화를 관찰하였다. 대조구로 대장균을 이용하였 으며 대조구는 배양됨에 따라 $\mathrm{pH}$ 가 약간 증가하는 것에 반해 분리균은 $\mathrm{pH}$ 가 점점 낮아져 $\mathrm{pH} 2.4$ 까지 감소하였음을 확인하 였다(Fig. 4).

\section{6s rDNA sequence}

항생제 저항성 조사에서 Kanamycin에 대한 저항성을 확인 하고 Kanamycin 을 첨가한 MRS agar 배지에 순수배양 하여 균 동정을 실시하였다. 균 동정 결과 GG-4는 Lactobacillus rhamnosus로 동정되어(Fig. 5, 6) 유산균임을 재확인하였다. 따 라서 균 이름을 L. rhamnosus GG-4로 명명하였다. 


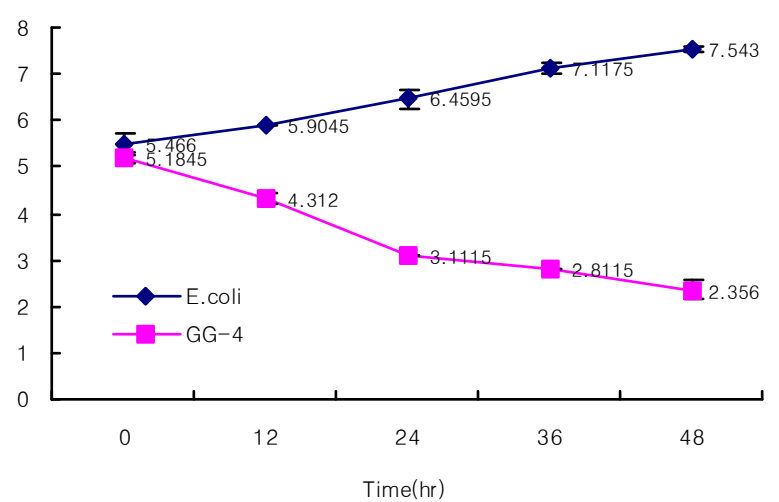

Fig. 4. $\mathrm{pH}$ change of culture media according to the culture time of L. rhamnosus GG-4.

\section{유산균 생균제의 산란계 급이 실험}

산란계에 대한 유산균 첨가 사료 급이 실험으로 악취물질 농도 조사 결과 악취물질은 전반적으로 대조구(비급이구)에 비해 실험구(급이구)에서 현저히 낮은 수치로 나타났다(Fig. 7). 특히 악취성분 중 황화수소는 급이구의 분변에서 악취 중 약 $80 \%$ 가 함유되어 있었으나 유산균을 먹인 닭의 분변에서는 $50 \%$ 가 감소함을 확인할 수 있었다. 암모니아는 함유된 절대 량은 상대적으로 적었지만 유산균 급이구에서는 약 $70 \%$ 가 감소함을 확인하였다. 닭의 외형적 비교에 있어서, 대조구와 급이구의 무게나 외관상 차이가 없었고, 달걀에 있어서 노른 자의 색도를 비교한 결과 대조구나 급이구가 별 차이가 관찰

5-'ATACATGCAGTCGAACGAGTTCTGATTATTGAAAGGTGCTTGCATCTTGATTTAATTTTGAACGAGTGGCGGACGGGTGAGTAACACGTGGGTAAC CTGCCCTTAAGTGGGGGATAACATTTGGAAACAGATGCTAATACCGCATAAATCCAAGAACCGCATGGTTCTTGGCTGAAAGATGGCGTAAGCTATCG CTTTTGGATGGACCCGCGGCGTATTAGCTAGTTGGTGAGGTAACGGCTCACCAAGGCAATGATACGTAGCCGAACTGAGAGGTTGATCGGCCACATT GGGACTGAGACACGGCCCAAACTCCTACGGGAGGCAGCAGTAGGGAATCTTCCACAATGGACGCAAGTCTGATGGAGCAACGCCGCGTGAGTGAA GAAGGCTTTCGGGTCGTAAAACTCTGTTGTTGGAGAAGAATGGTCGGCAGAGTAACTGTTGTCGGCGTGACGGTATCCAACCAGAAAGCCACGGCTA ACTACGTGCCAGCAGCCGCGGTAATACGTAGGTGGCAAGCGTTATCCGGATTTATTGGGCGTAAAGCGAGCGCAGGCGGTTTTTTAAGTCTGATGTG AAAGCCCTCGGCTTAACCGAGGAAGTGCATCGGAAACTGGGAAACTTGAGTGCAGAAGAGGACAGTGGAACTCCATGTGTAGCGGTGAAATGCGTA GATATATGGAAGAACACCAGTGGCGAAGGCGGCTGTCTGGTCTGTAACTGACGCTGAGGCTCGAAAGCATGGGTAGCGAACAGGATTAGATACCCT GGTAGTCCATGCCGTAAACGATGAATGCTAGGTGTTGGAGGGTTTCCGCCCTTCAGTGCCGCAGCTAACGCATTAAGCATTCCGCCTGGGGAGTAC GACCGCAAGGTTGAAACTCAAAGGAATTGACGGGGGCCCGCACAAGCGGTGGAGCATGTGGTTTAATTCGAAGCAACGCGAAGAACCTTACCAGGT CTTGACATCTTTTGATCACCTGAGAGATCAGGTTTCCCCTTCGGGGGCAAAATGACAGGTGGTGCATGGTTGTCGTCAGCTCGTGTCGTGAGATGTT GGGTTAAGTCCCGCAACGAGCGCAACCCTTATGACTAGTTGCCAGCATTTAGTTGGGCACTCTAGTAAGACTGCCGGTGACAAACCGGAGGAAGGTG GGGATGACGTCAAATCATCATGCCCCTTATGACCTGGGCTACACACGTGCTACAATGGATGGTACAACGAGTTGCGAGACCGCGAGGTCAAGCTAAT CTCTTAAAGCCATTCTCAGTTCGGACTGTAGGCTGCAACTCGCCTACACGAAGTCGGAATCGCTAGTAATCGCGGATCAGCACGCCGCGGTGAATAC GTTCCCGGGCCTTGTACACACCGCCCGTCACACCATGAGAGTTTGTAACACCCGAAGCCGGTGGCGTAACCCTTTTAGGGAGCGAGCCGT-3’

Fig. 5. 16S rDNA sequence of the GG-4 isolated from infant feces.

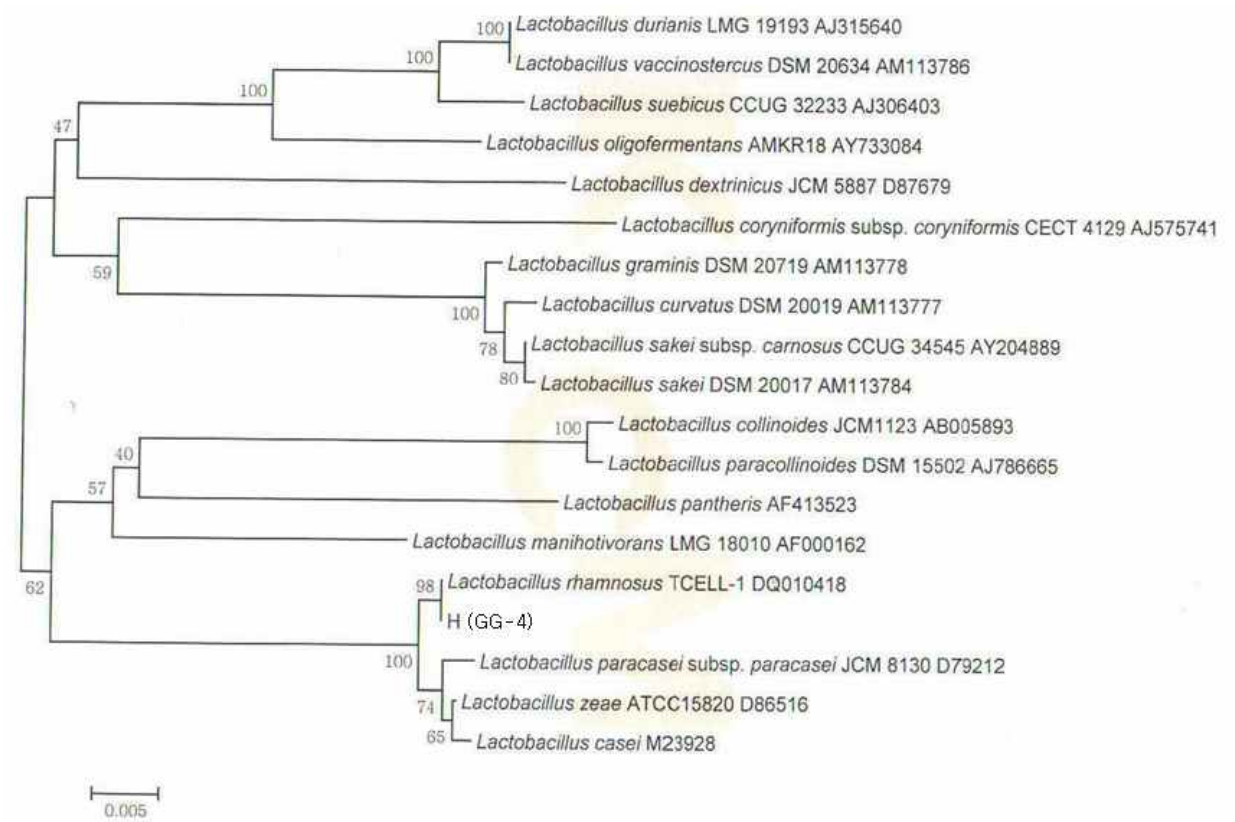

Fig. 6. Phylogenic analysis of the GG-4. 


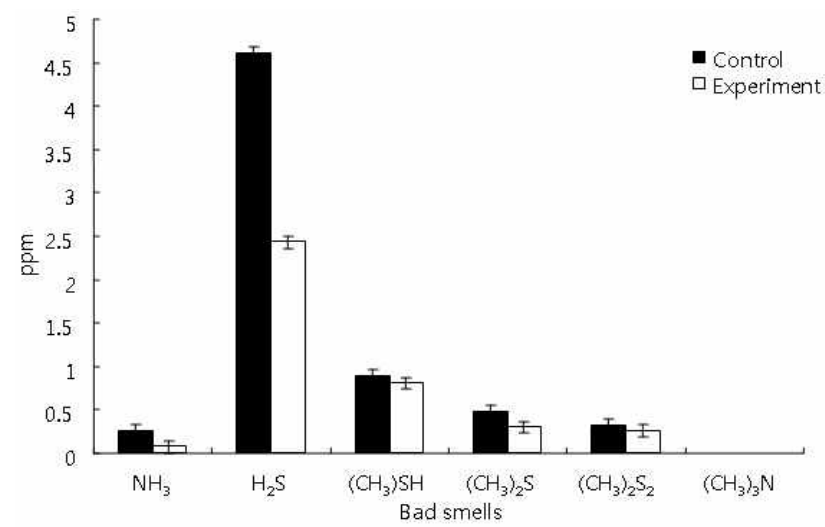

Fig. 7. Comparison of bad smells from feces of chickenfed feeds w/wo L. rhamnosus GG-4.

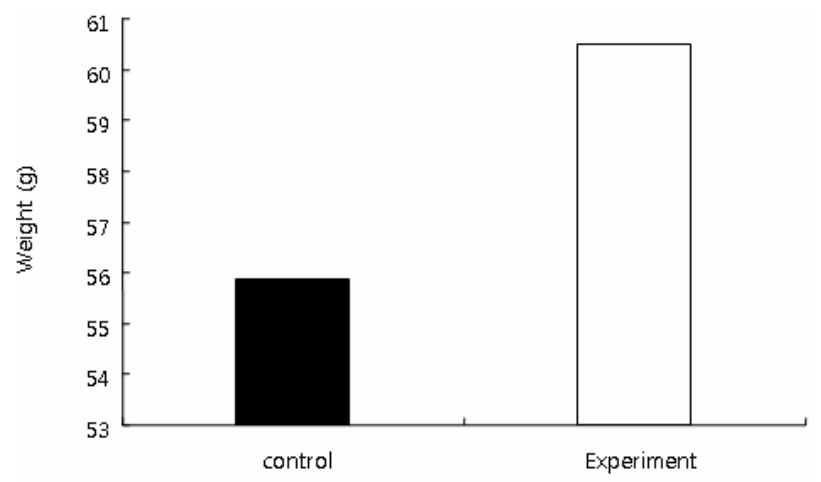

Fig. 8. Comparison of egg weights of chicken fed feeds w/wo L. rhamnosus GG-4.

되지 않았다. 달걀의 무게는 실험구가 대조구에 비해 $5 \pm 1$ $\mathrm{g}$ 더 무거워 진 것을 관찰하였다(Fig. 8). 이상의 결과를 종 합하면 유산균을 닭에 급이 하였을 때 관능 실험으로 닭 분변의 나쁜 냄새가 현저히 줄어들었고 급이구의 달걀 무 게가 $5 \mathrm{~g}$ 정도 무거워진 것은 상당한 의미가 있는 결과로 판단된다.

\section{감사의 글}

본 연구는 2009년 산청군 한방 약초 사업단의 연구비와 진 주산업대학교 기성회 연구비로 수행되었으며 이에 감사드립 니다.

\section{References}

1. Chan, R. C. Y., G. Reid, R. T. Irvin, A. W. Bruce, and J. W. Costerton. 1985. Competitive exclusion of uropathogens from human uroepitherial cells by Lactobacillus whole cells and cell wall fragment. Infect. Immun. 47, 84-89.

2. Fernandes, C. F., K. M. Shahani, and M. A. Amer. 1987. Therapeutic role of dietary Lactobacilli and lactobacillic fermented dairy products. FEMS Microbiol. Rev. 46, 343-356.

3. Gilliland, S. E. and M. L. Speck. 1977. Antagonistic action of Lactoba-cillus acidophilus toward intestinal and foodborne pathogens in associative cultures. J. Food Prot. 40, 820-823.

4. Gilliland, S. E. and D. K. Walker. 1990. Factors to consider when selecting a culture of Lactobacillus acidophilus as a dietary adjunct to produce a hypocholesterolemic effect in humans. J. Dairy Sci. 73, 905-911.

5. Isolauri, E., J. Joensuu, H. Suomalainen, M. Luomala, and T. Vesikari. 1995. Improved immunogenicity of oral Dx RRV reassortant rotavirus vaccine by Lactobacillus casei $G G$. Vaccine 13, 310-312.

6. Jang, Y. D., H. K. Oh, L. G. Piao, H. B. Choi, J. H. Yum, and Y. Y. Kim. Evaluation of probiotics as an alternative to antibiotic on growth performance, nutrient digestibility, occurrence of diarrhea and immune response in weaning pigs. 2009. J. Anim Sci. Technol. (Kor.) 51, 25-32.

7. Kitazawa, H., K. Matsumura, T. Itoh, and T. Yamaguch. 1992. Interferon inductionn in murine peritoneal macrophage by stiulation with Lactobacillus acidophilus. Microbiol. Immunol. 36, 311-315.

8. Klaenhammer, T. R. 1993. Gemetics of bacteriocins produced by lactic acid bacteria. FEMS Microbiol. Rev. 12, 39-85.

9. Lee, E. Y. 2008. Problems and verification system of probiotics as livestock-environment improving agent produced and circulated. Korean J. Microbiol. Biotechnol. 36, 87-95.

10. Lee, S. B. and S. H. Choi. 2006. Isolation and identification of probiotic Lactobacillus isolates for Calf Meal Supplements. Korean J. Food Sci. Ani. Resour. 26, 106-112.

11. Lee, S. H., E. H. Yang, H. S. Kwon, J. H. Kang, and B. H. Kang. 2008. Potential probiotic properties of Lactobacillus johnsonii IDCC 9203 isolated from infant feces. Korean J. Microbiol. Biotechnol. 36, 121-127.

12. Lee, S. H. and M. J. No. 1997. Viability in artificial gastric and bile juice and antimicrobial activity of some lactic acid bacteria isolated from Kimchi. Korean J. Microbiol. Biotechnol. 25, 617-622. 
초록 : 유아분변으로부터 분리한 Lactobacillus rhamonosus GG-4의 생균제적 특성

강진혜 · 김대환 · 이상원 · 김홍출 · 조용운 · 갈상완*

(진주산업대학교 제약공학과)

생균제 개발을 위하여 한 종류의 유산균을 유아 분변으로부터 분리하였다. 이 세균을 $16 \mathrm{~s} \mathrm{rDNA}$ 염기서열 분 석을 통하여 확인해 본 결과 Lactobacillus rhamnosus로 동정되었다. 이 유산균은 호기성 조건에서도 잘 자라는 통 성 혐기성 세균이었다. 이 유산균은 $\mathrm{MRS}$ 배지에 48 시간 액체 배양하였을 때 배양액의 $\mathrm{pH}$ 를 2.4 까지 낮추는 것을 확인 하였다. 이 유산균은 6 종의 병원성 세균, L. monocytogenes, S. aureus, P. aeruginosa, V. parahaemolyticus, S. typhimurium, and E. coli $\mathrm{O} 157$ 의 생육을 저해하는 것을 확인하였다. 이 유산균을 시판 중인 닭 사료에 섞어 먹인 후 분변의 악취를 조사하였을 때, 분변의 악취 중 약 $80 \%$ 를 차지하는 황화수소는 대조구 보다 $50 \%$ 가 감소 하였고, 암모니아는 상대적으로 함유된 양은 적었지만 대조구 보다 $70 \%$ 가 감소하였음을 확인할 수 있었다. 유산 균 급이구와 대조구의 외형은 변화가 없었으며, 달걀 무게에 있어서 먹인 닭의 달걀이 평균 $5 \mathrm{~g}$ 정도 무거워진 것을 확인 할 수 있었다. 